\title{
Cloning and Characterization of Resistance Gene Analogues (RGAs) from Piper Nigrum L. cv. Semongok Aman and Piper Colubrinum Link
}

\author{
Lau Ee Tiing, Hwang Siaw San, Lily Eng, and Paulus Amin Det
}

\begin{abstract}
Resistance gene analogues (RGAs) have been isolated from many crops such as banana, cereals, sugarcane, wheat and tomato. Cloning and characterization of RGAs offer potential in breeding for disease resistant crops through marker-assisted selection. Resistance genes from a broad range of plant species are known to share similarities in amino acid structural motifs. A pair of degenerate oligonucleotide primers designed from conserved motifs of P-loop and GLPL regions, common to many resistance genes, were used to amplify the Nucleotide-Triphosphate Binding Site (NBS) regions of RGAs from two Piper species, Piper nigrum L. cv. Semongok Aman and Piper colubrinum Link. A total of ten (10) partial RGAs fragments designated as PcRGAt5, PcRGAt6, PcRGAt7, PcRGAt8 and PcRGAt9 amplified from Piper colubrinum Link.; PnRGAt10, PnRGAt11, PnRGAt12, PnRGAt13 and PnRGAt14 amplified from Piper nigrum cv. Semongok Aman have been sequenced and characterized. The cloned partial RGAs with sequence length ranged from $498 \mathrm{bp}$ to $540 \mathrm{bp}$ encoding proteins with the size ranging from 165 amino acids to 179 amino acids. The predicted Piper RGA peptides contained the conserved motifs of Kinase-1 or the P-loop (GMGGVGKT), Kinase-2 (VLDDVW) and the hydrophobic Kinase-3 domain or GLPL. The obtained peptide sequences showed $42 \%$ to $47 \%$ similarity with published disease resistance proteins from various plant species such as Prunus persica (peach species) NBS resistance proteins, Malus baccata (apple species) and Prunus kansuensis (wild peach species) NBS-LRR-like proteins, Manihot esculenta (cassava) RCa9, RCa10.2 and RCa10.6 NBS type resistance proteins. An Un-weighted Pair Group Method with Arithmetical Averages (UPGMA) phylogenetic tree has been generated from the alignment of predicted Piper RGA peptides with the 6 published disease resistance proteins. The clustering analysis revealed that NBS-containing resistance genes comprise a large gene family in Piper species.
\end{abstract}

Index Terms - Clustering analysis, conserved motifs, disease resistant, piper nigrum L. cv. semongok aman, Piper colubrinum link., resistance gene analogues (RGAs).

\section{INTRODUCTION}

Black pepper is the world's most widely used spice for food flavoring. It is the fruit of the tropical climbing woody vine, Piper nigrum L., belonging to the family Piperaceae and native to South-western India. Vietnam, India, Brazil,

Manuscript received August 8, 2012; revised September 17, 2012.

L. E. Tiing is with the Research and Development Section, Malaysian Pepper Board, Sarawak, Malaysia (e-mail: lau@mpb.gov.my).

H. S. San is with the School of Engineering, Computing and Science, Swinburne University of Technology Sarawak, Malaysia (e-mail: shwang@swinburne.edu.my).

L. Eng and P. A. Det are with the Agriculture Research Centre Semongok, Department of Agriculture Sarawak, Malaysia (e-mail: lilye@sarawak.gov.my and paulusad@sarawak.gov.my).
Indonesia and Malaysia are the five main producers of black pepper in the world. In Malaysia, black pepper is mainly cultivated in the State of Sarawak and it contributes significantly to the rural population as a source of income.

Black pepper is susceptible to various pathogens which cause considerable yield loss every year. The major diseases found in pepper are foot rot caused by Phytophthora capsici, black berry caused by Colletotrichum capsici and Colletotrichum gloeosporioides and slow decline due to a disease complex caused by root-knot nematodes (Meloidogyne spp.) and the fungi, Fusarium spp.

Piper colubrinum Link is a woody shrub and is a wild relative of Piper nigrum L. It is native to the northern part of South America. This species is important because of its resistance to Phytophthora capsici and nematodes [1], [2], [3].

Grafting Piper nigrum L. shoots onto Piper colubrinum Link. Rootstocks had been carried out as a way of trying to solve the problems of soil-borne pathogens in pepper cultivation in Brazil, Malaysia and India [2], [4]. The grafted plants indicated high initial success but poor survival later due to the problem of delayed graft incompatibility [5], [6].

Wide hybridization between Piper colubrinum Link and Piper nigrum L. had been attempted in Malaysia, but there had been no success due mainly to the different ploidy levels and that the two species are cross incompatible [6]. With the development of biotechnological approaches, there is a lot of potential in transferring desirable resistance genes from Piper colubrinum Link. onto Piper nigrum L.

Genes conferring resistance to various pathogenic bacteria, fungi, nematode or viruses have been isolated from a variety of plant species [7], [8], [9]. Majority of the plant resistance genes encode cytoplasmic receptor-like proteins that contain Nucleotide-Triphosphate Binding Site (NBS) and Leucine-Rich Repeat (LRR) domains [10].

Motifs of these domains are well conserved in plant resistance genes and have been named as Resistance Gene Analogues (RGAs) [11] or Resistance Gene Candidates (RGCs) sequences [12]. Genetic analysis has associated the sequences of this group of genes to known gene loci that confer resistance to bacteria, fungi, nematode or viruses [11] - [17].

Examples of members of plant resistance genes from NBS-LRR gene family are Prf, I2CI and $M i$ from tomato [18], [19], [20], $N$ from tobacco [21], RPM1 from Arabidopsis [22], $M$ and $L 6$ from flax [23], [24], RGC2 from lettuce [25], Xal from rice [26] and $\mathrm{Cre} 3$ from wheat [27].

Plant resistance genes appear to encode components of 
signal transduction pathways and have been found to share significant homologies in DNA, amino acid and structural domains [7], [9]. The high degree of sequence conservation among the NBS-LRR domains of plant resistance genes has permitted the design of degenerate oligonucleotide primers for use in Polymerase Chain Reaction (PCR) amplification and cloning of RGAs from plant species.

In this study, we aimed to clone and characterize the RGAs in Piper species using degenerate oligonucleotide primers designed for recognition of conserved NBS domains.

\section{MATERIALS AND METHOD}

\section{A. Sampling}

Young leaves of Piper nigrum L. cv. Semongok Aman and Piper colubrinum Link. were collected from the Pepper Breeding Section of Agriculture Research Centre, Department of Agriculture Sarawak at Semongok, Kuching, Sarawak.

The leaf samples were wrapped with aluminum foil, kept in separate plastic bags, labeled and preserved in liquid nitrogen prior to storage at $-80^{\circ} \mathrm{C}$.

\section{B. Chemical Reagents and Solutions}

The RNA isolation buffer contained 2\% (w/v) cetyl trimethylammonium bromide (CTAB), 1\% (w/v) polyvinylpyrrolidone (PVP), 0.1M Tris-hydrochloric acid $(\mathrm{HCl})$ with $\mathrm{pH} 8.0,25 \mathrm{mM}$ ethylenediaminetetraacetic acid (EDTA) with $\mathrm{pH} 8.0,1.4 \mathrm{M}$ sodium chloride $(\mathrm{NaCl})$ and $1 \%(\mathrm{v} / \mathrm{v})$ betamercaptoethanol (added prior to use).

Chemical solutions prepared for RNA isolation comprised $0.1 \%(\mathrm{v} / \mathrm{v})$ diethyl- pyrocarbonate (DEPC) treated water, $3 \mathrm{M}$ sodium acetate $(\mathrm{NaOAc})$ with $\mathrm{pH} 5.2$, phenol:chloroform: isoamylalcohol $(25: 24: 1 \mathrm{v} / \mathrm{v})$, chloroform, cold isopropanol $\left(-20^{\circ} \mathrm{C}\right)$, cold absolute ethanol $\left(-20^{\circ} \mathrm{C}\right)$ and $75 \%(\mathrm{v} / \mathrm{v})$ ethanol.

\section{Total RNA Extraction and Purification}

Total RNAs were isolated from the young leaf tissues of Piper nigrum L. cv. Semongok Aman and Piper colubrinum Link. using modified ion detergent CTAB-based extraction method [28].

DNA contamination was eliminated using RQ1 RNase-free DNase (Promega, USA). The total 10 $\mu$ l DNase reaction volume contained 1X RQ1 RNase-free DNase reaction buffer $[40 \mathrm{mM}$ Tris- $\mathrm{HCl}$ with $\mathrm{pH} 8.0,10 \mathrm{mM}$ magnesium sulfate $\left(\mathrm{MgSO}_{4}\right), 1 \mathrm{mM}$ calcium chloride $\left(\mathrm{CaCl}_{2}\right)$ ] and 1 unit of RQ1 RNase-free DNase per $1 \mu \mathrm{g}$ of total RNA.

The reactions were carried out at $37^{\circ} \mathrm{C}$ for 30 minutes, followed by heat inactivating the DNase at $65^{\circ} \mathrm{C}$ for 10 minutes with 0.1 volume of RQ1 DNase stop solution [20mM ethylene glycol tetraacetic acid (EGTA) with pH 8.0].

The purified RNA was treated with equal volume of phenol:chloroform:isoamylalcohol $(25: 24: 1, \mathrm{v} / \mathrm{v})$, followed by equal volume of chloroform and recovered through 1 volume of cold isopropanol $\left(-20^{\circ} \mathrm{C}\right)$ precipitation prior stored at $-80^{\circ} \mathrm{C}$.

The qualities of the isolated total RNAs were analyzed through gel electrophoresis. The electrophoresis apparatus were pre-treated with $0.1 \%(\mathrm{v} / \mathrm{v})$ DEPC treated water. The RNA samples were electrophoresed on $1.2 \%(\mathrm{w} / \mathrm{v})$ agarose gels for an hour at $100 \mathrm{~V}$ in $0.1 \%(\mathrm{v} / \mathrm{v})$ DEPC treated $1 \mathrm{X}$ TBE (90mM Tris-borate, 2mM EDTA with pH 8.0, 1X SYBR ${ }^{\circledR}$ Safe DNA gel stain) buffer.

The stained gels were visualized using Safe Imager ${ }^{\mathrm{TM}} 2.0$ Blue-Light Trans- illuminator and documented using the AlphaImager $^{\circledR}$ HP Gel Documentation System (Alpha Innotech Corporation, South Africa).

The isolated total RNAs were quantified with the Gene-Quant 1300 UV Spectrophotometer (GE Healthcare Bio Science, UK) at wavelengths of $230 \mathrm{~nm}, 260 \mathrm{~nm}$ and $280 \mathrm{~nm}$ with a dilution factor equal of 100 .

\section{Reverse Transcriptase-Polymerase Chain Reaction (RT-PCR) Analysis}

First-strand cDNA templates were prepared from the isolated total RNAs using ImProm-II ${ }^{\mathrm{TM}}$ Reverse Transcription System (Promega, USA).

The total $20 \mu \mathrm{l}$ reverse transcription volume contained $1 \mathrm{X}$ ImProm-II $^{\mathrm{TM}}$ reaction buffer, $3 \mathrm{mM}$ magnesium chloride $\left(\mathrm{MgCl}_{2}\right), 0.5 \mathrm{mM}$ each dNTP mix, $1 \mathrm{U} / \mu \mathrm{l}$ recombinant RNasin $^{\circledR}$ ribonuclease inhibitor, $1 \mu \mathrm{l}$ ImProm-II ${ }^{\mathrm{TM}}$ reverse transcriptase (Promega, USA) and $0.5 \mu \mathrm{g}$ of oligo $(\mathrm{dT})_{15}$ primer per $1 \mu \mathrm{g}$ of total RNA.

The reverse transcriptions were carried out with 5 minutes of initial RNA incubation at $70^{\circ} \mathrm{C}$ to remove RNA secondary structures, followed by 5 minutes of annealing at $25^{\circ} \mathrm{C}$ and 60 minutes of first-strand extension at $42^{\circ} \mathrm{C}$. The reactions were terminated by heat inactivating the ImProm-II ${ }^{\mathrm{TM}}$ reverse transcriptase at $70^{\circ} \mathrm{C}$ for 15 minutes to prevent the reverse transcriptase from binding to newly synthesized first-strand cDNA.

A pair of degenerate oligonucleotide primers designed to amplify from the P-loop to the GLPL domain was chosen for Polymerase Chain Reaction (PCR). The forward primer from the P-loop was CNL298F with the nucleotide sequence 5'-GGN ATG GGN GGN GTN GGN AAR AC-3' encoding the amino acid sequence GMGGVGKT and the reverse primer was NBSIR, 5'-CGT CTT TGC MGC NAR NGG NAA NCC-3' [29].

PCR amplifications were carried out using the Applied Biosystem Thermal Cycler with Gradient Features. The total $25 \mu \mathrm{l}$ of PCR reaction mixture contained $1 \mathrm{X}$ PCR buffer [20mM Tris- $\mathrm{HCl}$ with $\mathrm{pH} 8.4,50 \mathrm{mM}$ potassium chloride (KCl)], $1.5 \mathrm{mM} \mathrm{MgCl}_{2}, 0.2 \mathrm{mM}$ each dNTP mix, $0.4 \mu \mathrm{M}$ forward and reverse oligonucleotide primers, 1 unit Taq DNA polymerase (Invitrogen, USA) and $1.0 \mu \mathrm{l}$ of first-strand cDNA templates.

PCR cycles were performed with 5 minutes of initial denaturation at $94^{\circ} \mathrm{C}$, followed by 35 cycles of 1 minute of denaturation at $94^{\circ} \mathrm{C}, 1$ minute of annealing at $55^{\circ} \mathrm{C}$ and 2 minutes of extension at $72^{\circ} \mathrm{C}$, and ending with 5 minutes of final extension at $72^{\circ} \mathrm{C}$.

\section{E. Cloning of Partial RGA cDNAs}

The RT-PCR amplified partial $R G A$ fragments were analyzed using 1 X SYBR ${ }^{\circledR}$ Safe DNA gel stained $1.5 \%(\mathrm{w} / \mathrm{v})$ agarose gels and purified using PureLink ${ }^{\mathrm{TM}}$ Quick Gel Extraction Kit (Invitrogen, USA). 
Gel slices containing the PCR amplicons were dissolved with 3 gel volumes of kit supplied Solubilization Buffer L3 at $50^{\circ} \mathrm{C}$ for 15 minutes. To bind cDNAs, the reactions were applied to Quick Gel Extraction Columns. Supernatants were discarded through centrifugation at $16,627 \mathrm{~g}$ for 1 minute at room temperature. The cDNAs bound on the membrane of the columns were washed with kit supplied Wash Buffer W1 and eluted into the recovery tubes by Elution Buffer E5.

The purified PCR amplicons were cloned using pGEM $^{\circledR}-\mathrm{T}$ Easy Vector System I (Promega, USA). The total $10 \mu \mathrm{l}$ ligation volume contained $1 \mathrm{X}$ rapid ligation buffer, 50ng pGEM $^{\circledR}$-T Easy vectors, 3 Weiss units T4 DNA ligase and $3 \mu \mathrm{l}$ of PCR amplicons. Ligation was carried out overnight at $4^{\circ} \mathrm{C}$ prior transformation of recombinant plasmid DNAs into high efficiency Escherichia coli JM109 competent cells.

Transformed plasmid DNAs were purified using PureLink $^{\text {TM }}$ Quick Plasmid Miniprep Kit (Promega, USA) through centrifugation. Bacterial cultures were lysated with kit supplied Cell Lysis Buffer CLC and neutralized using Neutralization Solution NSC.

To bind plasmid DNAs, the neutralized lysate were pipetted into PureYield ${ }^{\mathrm{TM}}$ Minicolumn and centrifuged at $16,627 \mathrm{~g}$ for 15 seconds at room temperature. The flow-through was discarded. The plasmid DNAs bound on the silica-membranes of the columns were initially washed with kit supplied Endotoxin Removal Wash (ERB) buffer followed by Column Wash Solution CWC and finally eluted using Elution Buffer EBB. The purified recombinant plasmids DNAs were sequenced.

\section{F. Sequence Analysis of Predicted Partial RGA Peptides}

The sequenced partial RGA fragments were edited using CHROMAS 2.30 to remove cloning vector sequences. Individual RGA sequences were translated and searched against GenBank non-redundant protein sequences using Basic Local Alignment Search Tool (BLASTX) for sequence homology searches.

Multiple alignments of Piper RGA peptides with published NBS type disease resistance proteins from various plants were performed using ClustalW algorithm. The output of alignment analysis was displayed via BoxShade server of the European Molecular Biology Network (EMBnet) retrieved from http://www.ch.embnet.org/software/BOX_form.html.

The conserved motifs of Kinase-1 or the P-loop (GMGGVGKT), Kinase-2 (VLDDVW) and the hydrophobic Kinase-3 domain or GLPL were predicted from the alignments. Cluster analyses of Piper RGA peptides with published NBS type disease resistance proteins were carried out using Molecular Evolutionary Genetics Analysis (MEGA) software [30].

A phylogenetic tree was constructed through Un-weighted Pair Group Method with Arithmetical Averages (UPGMA) method with bootstrap test (1000) for evaluating the reliability of the inferred UPGMA trees.

\section{RESUlTS AND DisCUSSIONS}

High quality total RNAs were successfully isolated from the young leaves of Piper nigrum L. cv. Semongok Aman and Piper colubrinum Link. Fig. 1 shows the $1.2 \%$ (w/v) gel electrophoresis of isolated RNAs. The distinct $25 \mathrm{~S}$ and $18 \mathrm{~S}$ ribosomal RNA bands were viewed on $1 \mathrm{X} \mathrm{SYBR}^{\circledR}$ Safe DNA gel stained agarose gel.

Ribosomal RNA represents more than $90 \%$ of the total RNAs [31]. Any degradation occurring during the RNA preparations can be easily viewed as smearing or indistinct bands. Therefore, the presence of distinct ribosomal RNA bands in Fig. 1 indicated little or no RNA degradation occurred during isolation process.

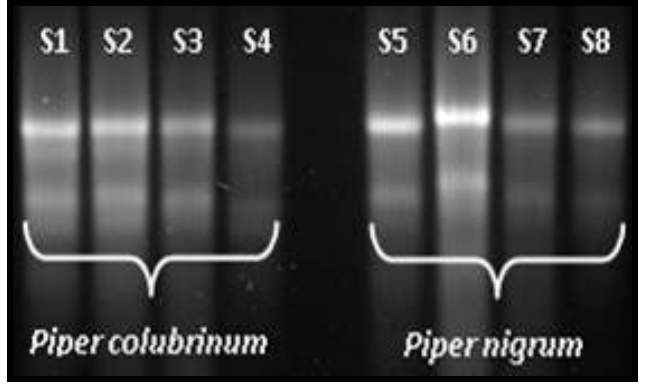

Fig. 1. 1.2\% (w/v) Agarose gel electrophoresis of total RNAs isolated from the young leaves of piper nigrum L. Cv. Semongok Aman and piper colubrinum link. using modified ion detergent ctab-based extraction method [28]; Lanes S1 to S4, isolated total rnas of piper colubrinum link.; lanes S5 to $\mathrm{S} 8$, isolated total rnas of piper nigrum $\mathrm{L}$. $\mathrm{Cv}$. semongok aman.

Table I shows the spectrophotometric evaluation of RNA samples. The RNA yields ranged from $24.2 \mu \mathrm{g}$ to $61.0 \mu \mathrm{g}$ of total RNAs per gram of fresh leaf tissues. The high purity of isolated RNAs was determined by the absorbance ratios of $\mathrm{A}_{260} / \mathrm{A}_{230}$ and $\mathrm{A}_{260} / \mathrm{A}_{280}$.

The $\mathrm{A}_{260} / \mathrm{A}_{230}$ absorbance ratio indicates polysaccharide or polyphenolic contamination; and the $\mathrm{A}_{260} / \mathrm{A}_{280}$ absorbance ratio indicates protein contamination [32], [33].

The $\mathrm{A}_{260} / \mathrm{A}_{230}$ absorbance ratios of isolated RNAs were within 1.7 to 2.0 ; indicating weak contamination of polysaccharides and polyphenolics [34], [35], [36]. Meanwhile, the $\mathrm{A}_{260} / \mathrm{A}_{280}$ absorbance ratios of the isolated RNAs ranging from 1.6 to 2.0, suggested less contamination of protein substances during RNA preparations [34], [35], [37].

TABLE I: SPECTROPHOTOMETRIC EVALUATIONS OF TOTAL RNAS ISOLATEd From the Young LEAVES OF PIPER NIGRUM L. CV. SEMONGOK AMAN AND PIPER COLUBRINUM LINK. USING MODIFIED ION DETERGENT CTAB-BASED EXTRACTION METHOD

\begin{tabular}{cccc}
\hline \hline RNA Samples & \multicolumn{2}{c}{${ }^{1}$ Absorbance ratios } & ${ }^{2}$ Yield $(\mu \mathrm{g} / \mathrm{g})$ \\
\cline { 2 - 3 } & $\mathrm{A}_{260 / 230}$ & $\mathrm{~A}_{260 / 280}$ & \\
\hline S1 & 1.790 & 1.801 & 56.2 \\
S2 & 2.000 & 1.859 & 63.2 \\
S3 & 1.837 & 1.824 & 49.6 \\
S4 & 2.608 & 1.583 & 26.6 \\
S5 & 1.784 & 1.930 & 61.0 \\
S6 & 1.350 & 1.929 & 43.2 \\
S7 & 1.043 & 2.017 & 24.2 \\
S8 & 1.593 & 1.957 & 27.4 \\
\hline \hline
\end{tabular}

${ }^{1}$ Results are presented as the mean of 3 absorbance readings.

${ }^{2}$ Yields of isolated total RNAs per gram of fresh young leaf tissues used.

The intactness of isolated RNAs was confirmed through reverse transcriptase-PCR (RT-PCR). Fig. 2 shows the $1.5 \%$ (w/v) gel electrophoresis of amplified partial Piper RGA fragments. RT-PCR amplicons with approximate size of $500 \mathrm{bp}$ were viewed as distinct fragments on $1 \mathrm{X} \mathrm{SYBR}{ }^{\circledR}$ Safe DNA gel stained agarose gel.

A total of ten positive clones were sequenced and 
designated as PcRGAt5, PcRGAt6, PcRGAt7, PcRGAt8, PcRGAt9 (amplified from Piper colubrinum Link.); and PnRGAt10, PnRGAt11, PnRGAt12, PnRGAt13, PnRGAt14 (amplified from Piper nigrum L. cv. Semongok Aman).

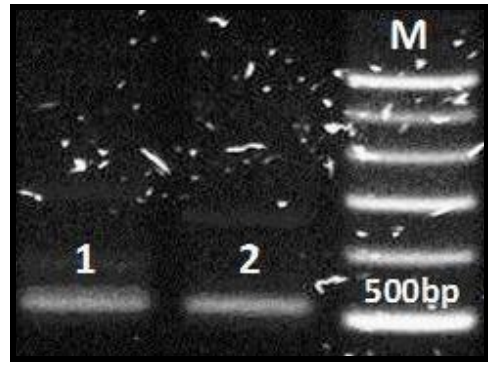

Fig. 2. $1.5 \%(w / v)$ Agarose gel electrophoresis of RT-PCR amplifications of Piper RGA fragments using degenerate oligonucleotide primer pair CNL298F/NBSIR; lane1, partial rga fragment of piper nigrum L. Cv. semongok aman; lane 2, partial rga fragment of piper colubrinum link.; lane $\mathrm{m}, 100 \mathrm{bp}$ dna ladder (promega, usa).

The cloned partial Piper RGA sequence lengths ranged from $498 \mathrm{bp}$ to $540 \mathrm{bp}$ encoding proteins with size ranging from 165 amino acids to 179 amino acids.

BLASTX database search programme indicated partial peptide sequences of Piper RGAs were $42 \%$ to $47 \%$ similar to the published disease resistance proteins of various plants, i.e. Prunus persica (peach species) NBS resistance proteins, Malus baccata (apple species) and Prunus kansuensis (wild peach species) NBS-LRR-like proteins, Manihot esculenta (cassava) RCa9, RCa10.2 and RCa10.6 NBS type resistance proteins.

Table II shows the sequence homology tests of partial Piper RGA peptides against the GenBank non-redundant protein sequences.

TABLE II: BLASTX SEQUENCE HOMOLOGY SEARCHES OF PARTIAL PIPER RGA PEPTIDES AGAINST THE GENBANK NON- REDUNDANT PROTEIN SEQUENCES

\begin{tabular}{llcc}
\hline \hline \multicolumn{1}{c}{ Plant species } & Protein types & $\begin{array}{c}\text { Query } \\
\text { Coverage }\end{array}$ & $\begin{array}{c}\text { Identity } \\
(\%)\end{array}$ \\
\hline Prunus persica & $\begin{array}{l}\text { NBS resistance } \\
\text { (AEB61537.1) }\end{array}$ & $99 \%$ & 42 \\
Malus baccata & $\begin{array}{l}\text { NBS-LRR-like } \\
\text { (AED99146.1) }\end{array}$ & $99 \%$ & 47 \\
Prunus kansuensis & $\begin{array}{l}\text { NBS-LRR-like } \\
\text { (ADO66738.1) }\end{array}$ & $99 \%$ & 43 \\
$\begin{array}{l}\text { Manihot esculenta } \\
\text { RCa9 }\end{array}$ & $\begin{array}{l}\text { NBS resistance } \\
\text { (AAO38220.1) }\end{array}$ & $98 \%$ & 42 \\
$\begin{array}{l}\text { Manihot esculenta } \\
\text { RCa10.2 }\end{array}$ & $\begin{array}{l}\text { NBS resistance } \\
\text { (AAP30045.1) }\end{array}$ & $97 \%$ & 41 \\
$\begin{array}{l}\text { Manihot esculenta } \\
\text { RCa10.6 }\end{array}$ & $\begin{array}{l}\text { NBS resistance } \\
\text { (AAP30049.1) }\end{array}$ & $97 \%$ & 45 \\
\hline \hline
\end{tabular}

The presence of conserved motifs, i.e. Kinase- 1 or the P-loop (GMGGVGKT), Kinase-2 (VLDDVW) and the hydrophobic Kinase-3 domain or GLPL, as shown in Fig. 3, proves that it is effective to isolate and clone RGAs from Piper species based on the domains conserved among the known plant resistance genes.

The P-loop in NBS domain of plant RGAs has been reported to interact directly with the phosphate of the bound nucleotides and has been well characterized for adenosine triphosphate (ATP) and guanosine triphosphate (GTP) binding proteins [38], [39], [40], [41], [42]. Mutations of key residues in the P-loop can led to partial loss of the resistance gene ( $N$ gene) function in tobacco [7].

The Kinase- 2 motif of RGAs was reported to be involved in coordinating the ion magnesium $\left(\mathrm{Mg}^{2+}\right)$ required for phosphor-transfer reactions [41]. Protein arrangements occurring in the Kinase-2 to GLPL motifs are corresponding to the specificity of the NBS downstream signaling activation of coil-coiled domains [29].

Thus, the P-loop, Kinase-2 and the GLPL motifs of Piper RGAs detected in the present study are believed to play an important role for ATP binding and hydrolysis; and in signal transduction, triggered by the presence of the pathogen [43].
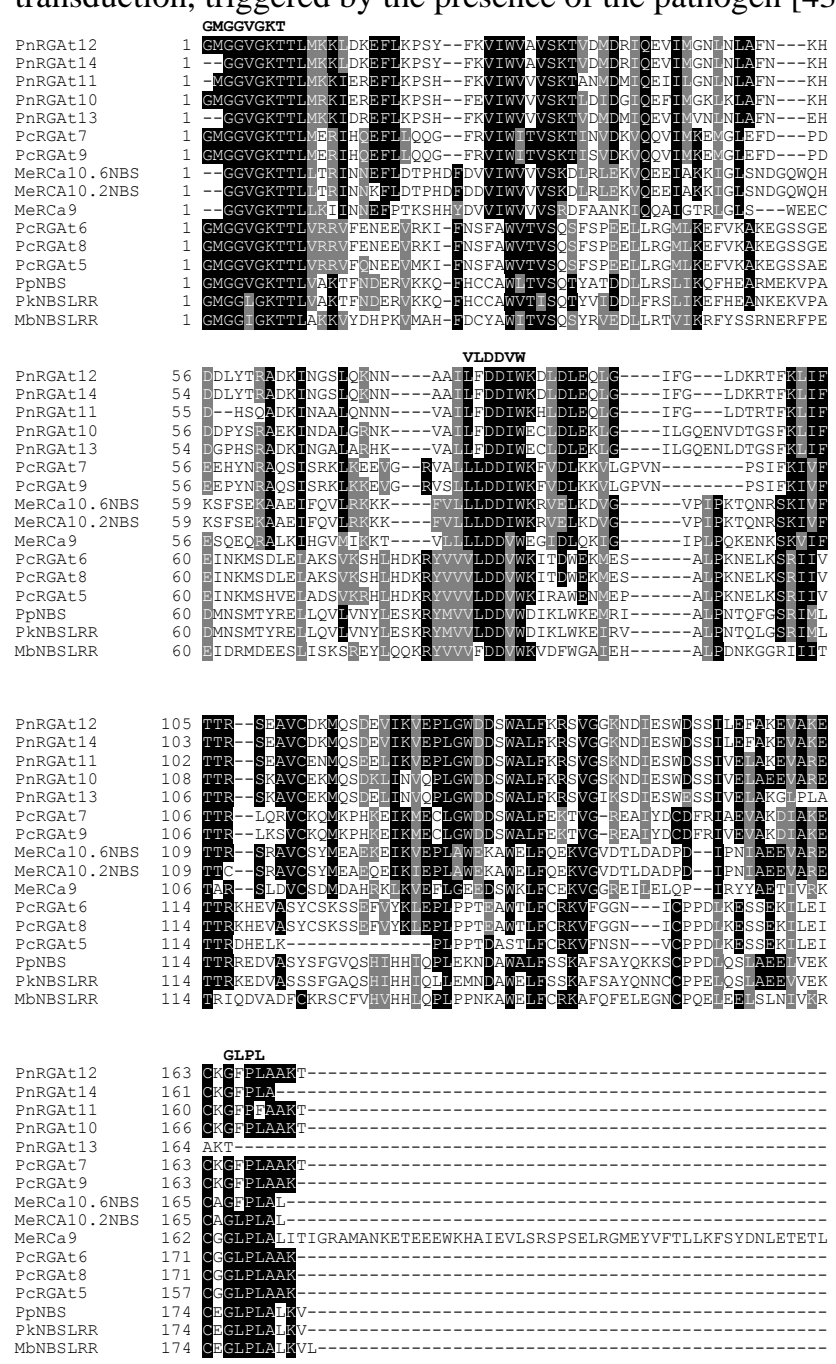

Fig. 3. Multiple alignments of predicted partial piper rga peptides with 6 published disease resistance proteins from genbank, i.e. prunus persica (peach species) nbs resistance proteins (accession no: aeb61537.1); malus baccata (apple species) and prunus kansuensis (wild peach species) nbs-lrr-like proteins (accession no: aed99146.1 and ado66738.1); manihot esculenta (cassava) rca9, rca10.2 and rca10.6 nbs type resistance proteins (accession no: aao38220.1, aap30045.1 and aap30049.1) using clustalw algorithm. identical amino acids are in reverse color. conservative substitutions are shaded using online boxshade programme. sequence comparison shows the presence of conserved motifs of kinase-1 or the p-loop (gmggvgk), kinase-2 (vlddvw) and the hydrophobic kinase-3 domain or glpl, indicated by bolded letters on top of the alignments.

Fig. 4 shows the Un-weighted Pair Group Method with Arithmetical Averages (UPGMA) phylogenetic tree constructed from multiple alignments of the cloned partial 
Piper peptide sequences with 6 published NBS type disease resistance proteins carried out via Molecular Evolutionary Genetics Analysis (MEGA) software [30].

The PcRGAt7 and PcRGAt9 isolated from the Piper colubrinum Link. were found clustered closely with the five partial RGA peptides, i.e. PnRGA10, PnRGA11, PnRGA12, PnRGA13 and PnRGA15 amplified from the Piper nigrum L. cv. Semongok Aman.

The other three members of Piper colubrinum Link. RGA proteins, i.e. PcRGAt5, PcRGAt6 and PcRGAt8 were clustered close to the Prunus persica (peach species) NBS resistance proteins, Malus baccata (apple species) and Prunus kansuensis (wild peach species) NBS-LRR-like proteins.

These results indicate that NBS-containing resistance genes comprise a large gene family in Piper species. Thus, further studies are needed to isolate more novel Piper RGAs, study the full-length gene sequences and evaluate the role of these genes in disease resistance.

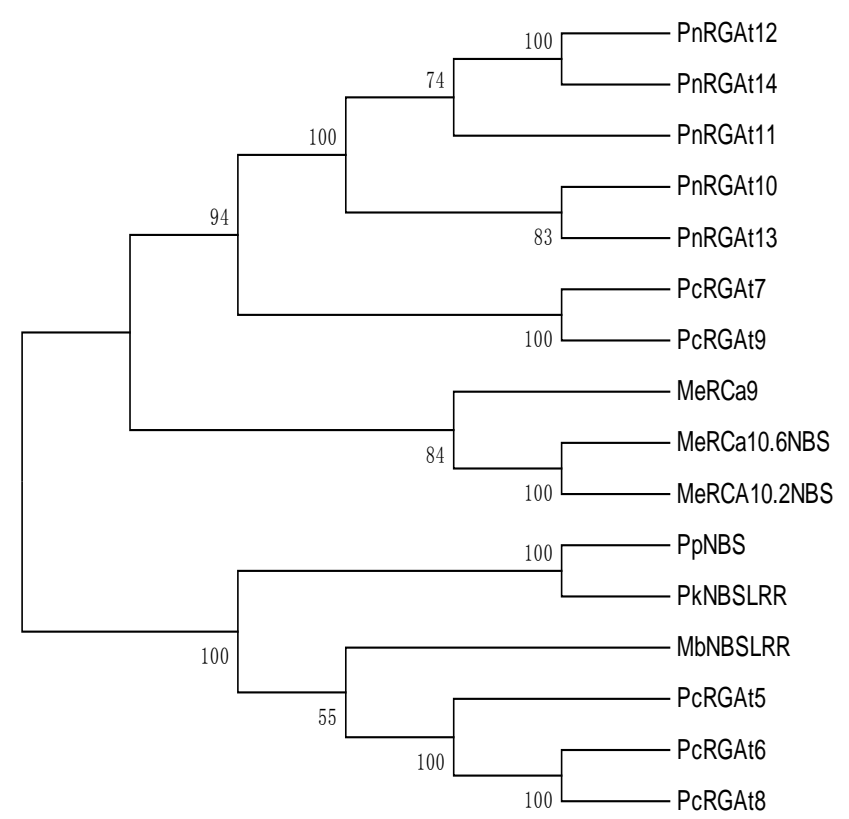

Fig. 4. UPGMA phylogenetic tree generated from the alignment of predicted partial piper rga peptides with 6 published disease resistance proteins from genbank, i.e. prunus persica (peach species) nbs resistance proteins (accession no: aeb61537.1); malus baccata (apple species) and prunus kansuensis (wild peach species) nbs-lrr-like proteins (accession no: aed99146.1 and ado66738.1); manihot esculenta (cassava) rca9, rca10.2 and rca10.6 nbs type resistance proteins (accession no: aao38220.1, aap30045.1 and aap30049.1) using mega software. alignments were made using the default parameters of the clustalw algorithm. bootstrap values are indicated next to the relevant node.

\section{CONClusion}

In conclusion, RGAs in Piper were successfully cloned using degenerate primer pair CNL298F/NBSIR designed for identifying the nature and diversity of NBS domains in Musa spp. (banana) resistance genes [29].

The UPGMA dendrogram (Fig. 4) shows that PcRGAt7 and PcRGAt9 of Piper colubrinum Link. were clustered closely to the RGA members of Piper nigrum L.

The other three members of Piper colubrinum Link., PcRGAt5, PcRGAt6 and PcRGAt8 were found to be more related to the Prunus species and Malus baccata NBS-type proteins rather than PcRGAt7 and PcRGAt9. These results reveal that NBS-type resistance genes comprise a large gene family in Piper species.

A few pairs of degenerate primers designed for recognition of NBS domains in other plant resistance genes, viz. LM638/REV7 [44], S2/A2 [45], CNL298F/M1445R [29], 3F2/I3RI [43] and RGA51F/RGA51R [46] have been used to clone more novel RGAs in Piper species.

Besides that, gene specific primers used in conjunction with GeneRacer ${ }^{\mathrm{TM}}$ PCR primers were designed based on the partial $R G A s$ genes obtained in the present study to discover the full-length sequences and evaluate the role of these Piper resistance genes in disease resistance.

\section{ACKNOWLEDGMENT}

The authors would like to express their gratitude and sincere appreciation to Mr. Kueh Giok San and the field assistants from the Agriculture Research Centre at Semongok, Sarawak, for their excellent field assistance and sample collection.

Financial assistance by Malaysian Pepper Board is also acknowledged.

\section{REFERENCES}

[1] J. W. Purseglove, E. G. Brown, C. L. Green, and S. R. J. Robbins, in Spices, Longman Inc., New York, vol. 2, pp. 736-813, 1981.

[2] P. Ravindran and A. Remashree, "Anatomy of Piper colubrinum Link," Journal of Spices and Aromatic Crops 1998, vol. 7, no. 2, pp. 111-123.

[3] W. Tameling, S. Elzinga, P. Darmin, J. Vossen, F. Takken, M. Haring, and J. Cornelissen, "The tomato R gene products I-2 and Mi-1 are functional ATP binding proteins with ATPase activity," Journal of Plant Cell 2002, vol. 14, pp. 2929-2939.

[4] T. Vanaja, V. Neema, R. Rajesh, and K. Mammootty, "Graft recovery of Piper nigrum L. runner shoots on Piper colubrinum Link. Rootstocks as influenced by varieties and month of grafting," Journal of Tropical Agriculture 2007, vol. 45, no. 1-2, pp. 61-62.

[5] P. D. Waard and D. Zeven, "Outlines of perennial crop breeding," in Ferwaeeda FP, Wit F (Eds.), Pepper. H. Veenman and Zorern NV, Wageningen, 1969, pp. 409-426.

[6] S. Sim and J. Rosmah, "Botany and varietal improvement," in Sim S.L. and Lai K.F. (eds.) Pepper production Technology in Malaysia, Malaysian Pepper Board, 2011, pp. 289.

[7] B. Baker, P. Zambryski, B. Staskawicz, and S. P. D. Kumar, "Signaling in plant-microbe interactions," Journal of Science 1997, vol. 276, pp. 726-733.

[8] C. Gebhardt, "Plant genes for pathogen resistance-variation on a theme," Journal of Trends in Plant Sciences 1997, vol. 2, pp. 243-244.

[9] H.-K. KE and J. Jones, "Plant disease resistance genes," Journal of Annual Review of Plant Physiology and Plant Molecular Biology 1997, vol. 48 , pp. 575-607.

[10] S. Hulbert, C. Wehh, S. Smith, and Q. Sun, "Resistance gene complexes: Evolution and utilization," Journal of Annual Review of Phytopathology 2001, vol. 39, pp. 285-312.

[11] V. Kanazin, L. F. Marek, and S R. C. hoemaker, "Resistance gene analogs are conserved and clustered in soybean," in Proceedings of National Academy of Sciences of the United State of America 1996, vol. 93, pp. 11746-11750.

[12] K. A. Shen, B. C. Meyers, M. N. I. Faridi, D. B. Chin, D. M. Stelly, and R. W. Michelmore, "Resistance gene candidate identified by PCR with degenerate oligonucleotide primers map to clusters of resistance genes in lettuce," Journal of Molecular Plant-Microbe Interactions 1998, vol. 11, pp. $815-823$.

[13] M. G. Aarts, H. B. T. Lintel, E. B. Holub, J. L. Benyon, and W. Stiekema, "Pereira A. Identification of R-gene homologuous DNA fragments genetically linked to disease resistance loci in Arabidopsis thaliana," Journal of Molecular Plant-Microbe Interactions 1998, vol. 11, pp. 251-258. 
[14] D. Leister, A. Ballvora, F. Salamini, and C. Gebhardt, "A PCR-based approach for isolating pathogen resistance genes from potato with potential for wide application in plants," Journal of Nature Genetic 1996, vol. 14, pp. 421-429.

[15] S. Seah, K. Sivasithamparam, A. Karakousis, and E. S. Lagudah, "Cloning and characterization of a family of disease resistance gene analogs from wheat and barley," Journal of Theoretical and Applied Genetics 1998, vol. 97, pp. 937-945.

[16] E. Speulman, D. Bouchez, E. B. Holub, and J. L. Benyon, "Disease resistance gene homologs correlate with disease resistance loci of Arabidopsis thaliana," Journal of Plant Journal 1998, vol. 14, pp. 467-474.

[17] Y. Yu, G. R. Buss, and M. S. Maroof, "Isolation of a superfamily of candidate disease resistance genes in soybean based on a conserved nucleotide binding site," in Proceedings of National Academy of Sciences of the United State of America, 1996, vol. 93, pp. $11751-11756$.

[18] S. B. Milligan, J. Bodeau, J. Yaghoobi, I. Kaloshian, P. Zabel, and V. M. Williamson, "The root knot nematode resistance gene Mi from tomato is a member of the leusine zipper, nucleotide binding, leucine rich repeat family of plant genes," Journal of Plant Cell 1998, vol. 10, pp. 1307-1319.

[19] N. Ori, Y. Eshed, I. Paran, G. Presting, D. Aviv, S. Tanksley, D. Zamir, and R. Fluhr, "The I2C1 family from the wilt disease resistance locus I2 belongs to the nucleotide binding, leucine-rich repeat superfamily of plant resistance genes," Journal of Plant Cell 1997, vol. 9, pp. 521-532.

[20] J. M. Salmeron, G. E. Oldroyd, C. Rommens, S. R. Scofield, H. S. Kim, D. T. Lavelle, D. Dhalbeck, and B. J. Staskawicz, "Tomato Prf is a member of the leucine-rich repeat class of plant disease resistance genes and lies embedded within the Pto kinase gene cluster," Journal of Cell 1996, vol. 86, pp. 123-133.

[21] S. Whitham, S. D. Kumar, D. Choi, R. Hehl, C. Corr, and B. Baker, "The product of the tobacco mosaic virus resistance gene N: similarity to Toll and the Interleukin-1 receptor," Journal of Cell 1994, vol. 78, pp. 1101-1115.

[22] A. F. Bent, B. N. Kundel, D. Dahlbeck, K. L. Brown, R. Schmidt, J. Giraudat, J. Leung, and B. J. Staskawicz, "RPS2 of Arabidopsis thaliana: a leucine-rich repeat class of plant disease resistance genes," Journal of Science 1994, vol. 265, pp. 1856-1860.

[23] P. A. Anderson, G. J. Lawrence, B. C. Morrish, M. A. Ayliffe, J. Finnegan, and J. E. Ellis, "Inactivation of the flax rust resistance gene $\mathrm{M}$ associated with loss of a repeated unit within the leucine-rich repeat coding region," Journal of Plant Cell 1997, vol. 9, pp. 641-651.

[24] G. J. Lawrence, E. J. Finnegan, M. A. Ayliffe, and J. G. Ellis, "The L6 gene for flax rust resistance is related to the Arabidopsis bacterial resistance gene RPS2 and the tobacco viral resistance gene N," Journal of Plant Cell 1995, vol. 7, pp. 1195-1206.

[25] B. C. Meyers, K. A. Shen, P. Rohani, B. S. Gaut, and R. W. Michelmore, "Receptor-like genes in the major resistance locus of lettuce are subject to divergent selection," Journal of Plant Cell 1998, vol. 10, pp. 1833-1846.

[26] S. Yoshimura, U. Yamanouchi, Y. Katayose, S. Toki, Z. X. Wang, I. Kono, N. Kurata, M. Yano, N. Iwata, and T. Sasaki, "Expression of $\mathrm{Xa1}$, a bacterial blight-resistance gene in rice, is induced by bacterial inoculation," in Proceedings of the National Academy of Sciences, 1998, vol. 95 , pp. 1663-1668.

[27] E. S. Lagudah, O. Moullet, and R. Appels, "Map-based cloning of a gene sequence encoding a nucleotide binding domain and a leucine-rich region at the Cre3 nematode resistance locus of wheat," Journal of Genome 1997, vol. 40, pp. 659-665.

[28] E. T. Lau and W. S. Ho, "Molecular cloning and in silico characterization of full-length XET and CesA cDNA in Shorea parvifolia Dyer ssp. parvifolia," in M. Sc. Thesis of Plant Biotechnology, Faculty of Resource Science and Technology, Universiti Malaysia Sarawak, 2008.

[29] M. Azhar and J. H. Harrison, "Genome, diversity and resistance gene analogues in Musa species," Journal of Cytogenetic and Genome Research 2008, vol. 121, pp. 59-66.

[30] S. Kumar, K. Tamura, I. B. Jakobsen, and M. Nei, MEGA2: Molecular evolutionary genetics analysis software. Arizona State University, USA, 2001.

[31] M. H. Asif, P. Dhawan, and P. Nath, "A simple procedure for the isolation of high quality RNA from ripening banana fruit," Journal of Plant Molecular Biology Reporter 2000, vol. 18, pp. 109-115.

[32] J. Logemann, J. Schell, and L. Willmitzer, "Improved method for the isolation of RNA from plant tissues," Journal of Analytical Biochemistry 1987, vol. 163, pp. 16-20.
[33] K. Manning, "Isolation of nucleic acids from plants by differential solvent precipitation," Journal of Analytical Biochemistry 1990, vol. 195, pp. 45-50.

[34] C. G. Hu, C. Honda, M. Kita, Z. L. Zhang, T. Tsuda, and T. Moriguchi, "A simple protocol for RNA isolation from fruit trees containing high levels of polysaccharides and polyphenol compounds," Journal of Plant Molecular Biology Reporter 2002, vol. 20, pp. 69a-69g.

[35] M. Malnoy, J. P. Reynoird, F. Mourgues, E. Chevreau, and P. Simoneau, "A method for isolating total RNA from pear leaves," Journal of Plant Molecular Biology Reporter 2001, vol. 19, pp. 69a-69f.

[36] Y.Zeng and T. Yang, "RNA isolation from highly viscous samples rich in polyphenols and polysaccharides," Journal of Plant Molecular Biology Reporter 2002, vol. 20, pp. 417a-417e.

[37] H. H. Gehrig, K. Winter, J. Cushman, A. Borland, and T. Taybi, "An improved RNA isolation method for succulent plant species rich in polyphenols and polysaccharides," Journal of Plant Molecular Biology Reporter 2000, vol. 18, pp. 369-376.

[38] H. R. Bourne, D. A. Sanders, and F. McCormick, "The GTPase superfamily: conserved structure and molecular mechanism," Journal of Nature 1991, vol. 349, pp. 117-127.

[39] B. C. Meyers, A. W. Dickerman, R. W. Michelmore, S. Sivaramakrishnan, B. W. Sobral, and N. D. Young, "Plant disease resistance genes encode members of an ancient and diverse protein family within the nucleotide-binding superfamily," Journal of Plant 1999, vol. 20, pp. 317-332

[40] M. Saraste, P. R. Sibbald, and A. Wittinghofer, "The P-loop a common motif in ATP- and GTP-binding proteins," Journal of Trends in Biochemical Sciences 1990, vol. 15, pp. 430-434.

[41] T. W. Traut, "The functions and consensus motifs of nine types of peptide segments that form different types of nucleotide-binding sites," European Journal of Biochemistry 1994, vol. 222, pp. 9-19.

[42] J. E. Waker, M. Saraste, M. J. Runswick, and N. J. Gay, "Distantly related sequences in the $\alpha$ - and $\beta$ - subunits of ATP synthetase, myosin, kinases and other ATP-requiring enzymes and a common nucleotide-binding fold," Journal of European Molecular Biology Organization 1982, vol. 1, pp. 945-951.

[43] R. Miller, D. J. Bertioli, F. C. Baurens, C. Santos, and P. C. Alves, "Martins NF, Togawa RC, Junior MTS, Junior GJP. Analysis of non-TIR NBS-LRR resistance gene analogs in Musa acuminate Colla: Isolation, RFLP marker development, and physical mapping," Journal of Plant Biology 2008, vol. 8, no. 15

[44] J. C. Cordero and D. Z. Skinner, "Isolation from alfalfa of resistance gene analogues containing nucleotide binding sites," Journal of Theoretical and Applied Genetics 2002, vol. 104, pp. 1283-1289.

[45] H. Y. Wang, W. X. Yang, L. R. Zhang, Q. F. Meng, D. Q. Liu, and T. Zhang, "Isolation and characterization of resistance gene homology sequence from wheat," Journal of Phytopathology 2006, vol. 154, pp. 670-675

[46] S. S. Hwang, A. D. Paulus, and L. Eng, "Cloning and sequence analyses of Resistance Gene Analogs (RGAs) from Piper colubrinum," in Research Officers' Progress Meeting. Department of Agriculture Sarawak, 2009.

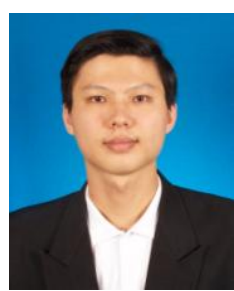

Lau Ee Tiing was born in Sibu, Sarawak, Malaysia on October 11st 1980. He obtained his Master of Science (M.Sc.) degree by research in plant biotechnology from the Universiti Malaysia Sarawak (UNIMAS), Kota Samarahan in 2008. He was offered UNIMAS zamalah scholarship for his M.Sc. study. He graduated with a Bachelor of Science (B.Sc.) degree with Honours in resource biotechnology from the UNIMAS in 2004. His research works were mainly focused on isolation, molecular cloning and characterization of novel or functional genes on plant species. He has published his M.Sc. research paper entitled "Molecular cloning of cellulose synthase gene, SpCesAl from developing xylem of Shorea parvifolia ssp. parvifolia" in the Journal of Biotechnology 8(4): 416-424. Till date, he has presented 8 papers in both international and national conferences. His papers include: Lau, E.T. Hwang, S.S., Eng L. and Paulus, A.D. 2012. Cloning and characterization of Resistance Gene Analogues (RGAs) from Piper nigrum L. cv. Semongok Aman and Piper colubrinum Link. APCBEES Procedia; Lau, E.T., Angela, T. and Zehnder, J. 2011. Strategy and innovation for sustainable pepper production and quality. $39^{\text {th }}$ Peppertech Meeting of International Pepper Community. Brandon, P.H.Y., Hwang S.S., Lily, E. and Lau, E.T. 2011 
Molecular characterization of Resistance Gene Analogs (RGAs) in Piper colubrinum. Proceedings of the $9^{\text {th }}$ Malaysia Genetics Congress (MGC9); Ho, W.S., Lau, E.T. and Julaihi, A. 2008. Molecular cloning and in silico characterization of CesA cDNA from Shorea parvifolia Dyer ssp. parvifolia. Proceedings of the $10^{\text {th }}$ Symposium of Malaysian Society; Lau, E.T., Ho, W.S. and Julaihi, A. 2006. Molecular cloning and characterization of full-length xyloglucan endotransglycosylase, SpXET1 cDNA from Shorea parvifolia Dyer ssp. parvifolia. Proceedings of the Applied Forest Science Research Seminar; Lau, E.T., Ho, W.S. and Julaihi, A. 2006. Isolation of cellulose synthase (CESA) and xyloglucan endotransglycosylase (XET) genes from Shorea parvifolia Dyer parvifolia. Proceedings of the Conference on Natural Resources; High quality total RNA isolation from Shorea parvifolia Dyer parvifolia tissues rich in secondary metabolites. Life Sciences Postgraduate Conference; Ho, W.S., Lau, E.T., Rosmah, J., Sim, S.L. and Paulus, A.D. 2005. Evaluation of genetic relatedness among pepper (Piper nigrum L.) accessions using direct amplification of minisatellite-region DNA (DAMD). Proceedings of the $6^{\text {th }}$ National Congress on Genetics. Author was employed as RESEARCH OFFICER by Malaysian Pepper Board (MPB), Kuching, Sarawak, Malaysia since 2009. His field of research was focused on pepper genetic analysis; aims to speed up genetic dissection in pepper and to develop knowledge of the structures and functions of pepper genome through biotechnology approaches.

Dr. Hwang Siaw San was born in Sri Aman, Sarawak, on 6 February 1974. She received her $\mathrm{PhD}$ in molecular biology in 2009 from Faculty of Resource Science and Technology, Universiti Malaysia Sarawak. Her early research was focused on defense response genes from oil palm (Elaies guineensis Jacq.), when she attached to Malaysian Palm Oil Board (MPOB) for her MSc. project (plant genetic engineering) in 2002, from Faculty of Food Science and Biotechnology, Universiti Putra Malaysia. She received her Bachelor of Science with Honours (resource biotechnology) in 1998, from Faculty of Resource Science and Technology, Universiti Malaysia Sarawak. She joined Swinburne University of Technology Sarawak Campus (SUTS) in 2010 as a LECTURER in Biochemistry and Molecular Biology. Prior to joining SUTS, she was a researcher at the Agrobiotech Branch of Agriculture Research Center (ARC), Department of Agriculture Sarawak. Her research experiences include molecular biology of disease resistance in crops and development of molecular marker for crops breeding programs. Her recent publications include: Lau, E.T., Hwang, S.S., Eng'L. and Paulus, A.D. 2012. Cloning and characterization of Resistance Gene Analogues (RGAs) from Piper nigrum L. cv. Semongok Aman and Piper colubrinum Link. APCBEES Procedia (Journal under Elsevier, ISSN: 2212-6708); Tiong, W.N., Hwang, S.S., Fong, A.Y.Y., Wee, C.C., Lai, L.Y.H., Tiong, L.L., Chang, B.C. and Ong, T.K. 2012. The Influence of CYP2C19*2 and *3 Polymorphisms on the Platelet Aggregation in Malaysian Chinese and non-Chinese Population. European Heart Journal Volume 14, Issue suppl A; and Tnah, L.H., Lee, C.T., Lee, S.L., Ng, K.S.K., Ng, C.H. and Hwang, S.S. 2011. Microsatellite Markers of an Important Medicinal Plant, Eurycoma Longifolia (Simaroubaceae), for DNA Profiling. American Journal of Botany, e1-e3. Her current research projects focus on cardiovascular pharmacogenomics which involve the study of variations of DNA and RNA characteristics as related to drug response (antiplatelet and anticoagulant), transcriptome analysis and gene expression profiling in Piper spp., study of resistance gene analogs (RGAs) from Piper spp. and wild banana, extraction of antioxidant compounds, and development of molecular-based methods for detection of plant pathogens to facilitate disease management in agricultural crops. Her current research interests including pharmacogenomics, molecular plant pathology and plant disease resistance, DNA profiling and

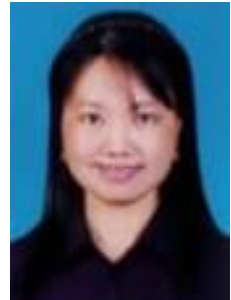

development of molecular markers for crop improvement, extraction and analyses of antioxidant She is a member of Sarawak Institute of Agriculture Scientist (SIAS) and Genetics Society of Malaysia. She has been awarded Swinburne Sarawak Seed Grant Scheme 2012 (Project account number: 2-5256). Title of research project is Cytochrome P4502C19 (*2, *3, *17) Allelic Variant, Platelet Aggregation and Clinical Outcome in Clopidogrel-treated Patients Prior to Coronary Angiography.

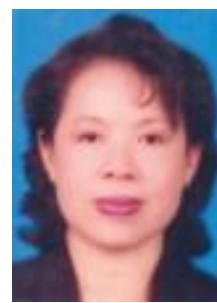

Dr. Lily Eng was born in Sibu, Sarawak, on 29 May 1957. She obtained her $\mathrm{PhD}$ in the biological control of root-knot nematodes from the University of Reading, United Kingdom in 2001; and her Bachelor of Agricultural Science degree in 1982 from La Trobe University, Melbourne, Australia. She is currently a SENIOR RESEARCHER and heads both teams in Plant Pathology and Agro-biotechnology at the Agriculture Research Centre of the Sarawak Department of Agriculture. She has conducted research on diseases of black pepper (Piper nigrum L.), citrus, paddy and chilli. Another of her job roles is to diagnose diseases of agricultural crops for farmers and growers. Apart from presenting conference papers at the International Pepper Community meetings on diseases of black pepper, she has co-authored the book "Manual for production of quality planting material for pepper" which was published in Malaysia by the Malaysian Pepper Board in 2011. She also authored a few chapters on black pepper diseases, good agricultural practices and XCROP-Pepper, an artificial intelligence software on black pepper crop health, in another two books: Pepper Production Technology in Malaysia and Malaysian Pepper Production Technology Manual, both published in Malaysia by the Malaysian Pepper Board. Dr. Lily Eng is a member of the Malaysian Society of Microbiologists, Malaysian Genetics Society and the Sarawak Institute of Agricultural Scientists. Her current research is on molecular identification of bacterial diseases of papaya and banana, as well as screening for paddy diseases.

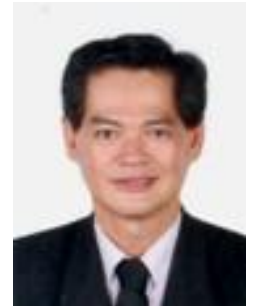

Paulus Amin Det was born in Kuching, Sarawak on 11 May 1956. He obtained his M. Phil. in plant breeding and crop improvement, a joint degree from the University of Birmingham and University of Reading in the United Kingdom in $1997 . \mathrm{He}$ graduated with a Bachelor of Agricultural Science degree from the University of Adelaide in 1980 . He is an ASSISTANT DIRECTOR OF AGRICULTURE in charge of Services and Administration at the Agriculture Research Centre of the Sarawak Department of Agriculture. Formerly, he was carrying out research on pepper, other spices and herbs. Apart from presenting conference papers at the International Pepper Community meetings on black pepper, he has co-authored the book "Manual for production of quality planting material for pepper" which was published in Malaysia by the Malaysian Pepper Board in 2011. He also authored a few chapters on cultural practices of black pepper in another two books: Pepper Production Technology in Malaysia and Malaysian Pepper Production Technology Manual, both published in Malaysia by the Malaysian Pepper Board. Mr. Paulus is a member of the Malaysian Genetics Society and the Sarawak Institute of Agricultural Scientists. 